\title{
Public Services User Satisfaction: An Application to Product of Government-Entity Business Project in West Java, Indonesia
}

\author{
Bihaki Ridwan $^{1}$, Pratikso ${ }^{2}$ \\ UPTD Management of Roads and Bridges Service Area IV, Office of Highways and Spatial \\ Planning, West Java Province, Indonesia ${ }^{1}$, Faculty of Engineering, Sultan Agung Islamic \\ University Semarang, Indonesia ${ }^{2}$ \\ \{Bihaki.ridwan1120@gmail.com ${ }^{1}$,
}

\begin{abstract}
The purpose of this study was to determine the effect of perceived service quality, perceived price, and perceived value on institution reputation through user satisfaction as a mediating variable on the results of the government-business entity cooperation (PPP) construction project in West Java Province. This type of research is causal research or explanatory research. This study was conducted in communities in the cities of Tasikmalaya, Cirebon, Indramayu, Majalengka, and Kuningan, West Java Province in DecemberJanuary 2021. The sample in this study were customers who used toll roads as a PPP project product in West Java Province. these are 115 respondents. Methods of data analysis using SEM-PLS. Based on the results of hypothesis testing, it was found that the research model consisting of: perceived service quality, user co-production, and perceived price has a positive and significant effect on user satisfaction with a determination coefficient of 0.795 or user satisfaction is influenced by perceived service quality, perceived price, and the perceived value is $79.5 \%$.
\end{abstract}

Keywords: Perceived Service Quality; Perceived Price; Perceived Value; Satisfaction; Institution Reputation

\section{Introduction}

One of the main elements of development policies in support of economic activity is the provision of adequate infrastructure, such as: electricity, drinking water supply, telecommunications, road facilities, and so on. Provision of infrastructure as a commodity with a public dimension (public goods) is the responsibility of the government. This means that the government is directly involved in providing infrastructure as a complement to the economic system that takes place within a community group or country. Less optimal infrastructure management implies that provinces with low infrastructure quality will find it difficult to compete in attracting foreign investors compared to other provinces with better infrastructure quality (Sultan et al., 2013) Development activities in West Java require support from the infrastructure side. The fact that there are links that have already been formed in real 
terms, as well as potential but not yet supported by the provision of adequate infrastructure is a challenge that needs to be answered in order to increase regional development. The form of efforts made to answer these challenges is by developing infrastructure provision programs.

The high level of FDI (Foreign Direct Investment) / foreign investment is also supported by the availability of infrastructure to remote areas where the investment will be carried out. However, with limited funds both from the APBN and APBD, infrastructure development cannot be fully carried out by the government (public). Therefore, the government will cooperate with investors (private / private) in implementing infrastructure development known as public private partnership or PPP(Yuniarti \& Junita, 2017).

In Government Regulation no. 38, 2015 concerning Public Private Parhership (PPP) in providing infrastructure, it is stated that this partnership aims to accelerate infrastructure development in which in partnership the two parties will share benefits and potential risks as well as support and incentives from the government (Wahyuni et al., 2018). For example, the PPP pattern in the City of Bandung is still limited to a number of infrastructures of relatively small value. The data shows that the infrastructure built with the PPP scheme includes: Revitalizing the New Market and the Ciroyom Healthy Market, while what will be built includes the development of Hasan Sadikin Hospital(Casnoto, 2017).

Measurement of the level of user satisfaction from infrastructure projects in collaboration between the government and business entities in West Java province has never been carried out, even though this is important feedback to find out whether cooperation in infrastructure project development carried out through government cooperation projects with business entities has met the level of community satisfaction. Therefore, a research was carried out on the level of satisfaction with the infrastructure project in collaboration with the government and business people in West Java Province. The research objective is to analyze the level of user satisfaction from the results of infrastructure projects from government cooperation with (private) enterprises in West Java province

\section{Methodology}

This research is a descriptive qualitative research type because it describes the facts or characteristics of a certain population by interpreting and analyzing data in the form of descriptions based on conditions and realities in the field (Sugiyono, 2017). Teknik purposive sampling digunakan dengan menetapkan sampel sebanyak 115 responden pengguna hasil produk proyek kontruksi di wilayah Tasikmalaya, Cirebon, Indramayu, Majalengka, dan Kuningan. Instrumen kuesioner dengan skala Likert yang diadaptasi dari (Duque, 2013), dan (Nguyen et al., 2018) untuk mengumpulkan data penelitian. Teknik SEM digunakan WarpPLS untuk menganalisis data penelitian ini. A key reason for the attractiveness of SEM is the possibility to (graphically) model and estimate parameters for relationships between theoretical constructs and to test complete behavioral sci- ence theories. SEM distinguishes between theoretical constructs and their empirical measurement by multiple observable variables(Henseler, 2017).

\section{Result and Discussion}

According Hair et al (2014), Goodness of fit measures the suitability of the observed / actual input with the prediction of the proposed model. There are 3 criteria for model fit 
indices or model suitability, namely the Average Path Coefficient (APC), Average R-square (ARS) and Average Variant Inflation Factor (AVIF). Following are the results of the fit Model output:

\begin{tabular}{ccc}
\multicolumn{3}{c}{ Table 1. Model Fit } \\
\hline Model & Fit Indices & P Values \\
\hline APC & 0.308 & $\mathrm{P}<0.001$ \\
ARS & 0.753 & $\mathrm{P}=0.001$ \\
AVIF & 1.851 & Good If $<0.5$ \\
\hline
\end{tabular}

From the output results in table 1 shows that the model indicator is fit with an average path coefficient (APC) $0.001<0.05$. While the Average R-squared (ARS) $0.001<0.05$. Likewise, the AVIF value is $1.851<5$, which means that the model has a good fit so that there is no multicollinearity problem between exogenous variables.

\section{a) Convergent Validity Test}

Convergent validity is assessed based on the correlation between the indicator score and the construct score (outer loading). According to Chin (1998), each indicator can be said to be valid if its outer loading value is greater than 0.7 . However, for research in the early stages of developing a measurement scale the loading value of 0.60 is considered sufficient (Ghozali, 2014). If an indicator does not meet these criteria, then the indicator is declared invalid and needs to be removed from the model.

Table 2. Outer Loading Value

\begin{tabular}{ccccc}
\hline Satisfaction (Y1) & PSQ (X1) & Price (X2) & Value (X3) & Reputation (Y2) \\
\hline-0.556 & 0.740 & 0.659 & 0.909 & 0.519 \\
0.728 & -0.247 & 0.634 & 0.919 & -0.118 \\
0.827 & 0.631 & -0.692 & -0.298 & 0.326 \\
0.685 & 0.545 & 0.571 & 0.257 & 0.743 \\
0.787 & 0.759 & & & 0.840 \\
\hline
\end{tabular}

Table 2 shows several indicators that have an outer loading value of less than 0.5 . On indicators with outer loading below 0.5 is Y1.1; X1.2; X3.3; X2.3; X2.4; Y2.2; and Y2.3. Indicators with outer loading values below 0.6 must be removed from the model. After eliminating indicators with a value below 0.6 , the outer loading results show that all items have a high level of validity. Outer loading value can be seen in table 3 below:

Table 3. Nilai Outer Loading Setelah Eliminasi

\begin{tabular}{ccccc}
\hline Satisfaction (Y1) & PSQ (X1) & Price (X2) & Value (X3) & Reputation (Y2) \\
\hline 0.784 & 0.732 & 0.942 & 0.592 & 0.522 \\
0.824 & 0.640 & 0.942 & 0.597 & 0.799 \\
0.717 & 0.589 & & 0.845 & 0.828 \\
0.769 & 0.749 & & & \\
\hline
\end{tabular}

Based on Table 3, it shows that all question items are said to be valid because the outer loading value is above 0.05 . So that it can be continued for structural model testing. Reliability Test A construct is said to be reliable as seen from its composite reliability value and Cronbach's alpha value. The construct is declared reliable if the composite reliability value is above 0.70 (Hair et al., 2014). 
Table 4. Reliability Test

\begin{tabular}{lcccc}
\hline \multicolumn{1}{c}{ Variables } & Cronbach's Alpha & Composite Reliability & AVE & Information \\
\hline Satisfaction (Y1) & 0.776 & 0.857 & 0.600 & Reliable \\
PSQ (X1) & 0.609 & 0.774 & 0.463 & Reliable \\
Price (X2) & 0.872 & 0.940 & 0.887 & Reliable \\
Value (X3) & 0.426 & 0.724 & 0.474 & Reliable \\
Reputation (Y2) & 0.545 & 0.767 & 0.532 & Reliabel \\
\hline
\end{tabular}

Based on Table 4, it shows that the value of Cronbach's alpha and Composite Reliability is more than 0.7 , so it can be concluded that the research instrument above has sufficient reliability.

\section{b) Inner Model}

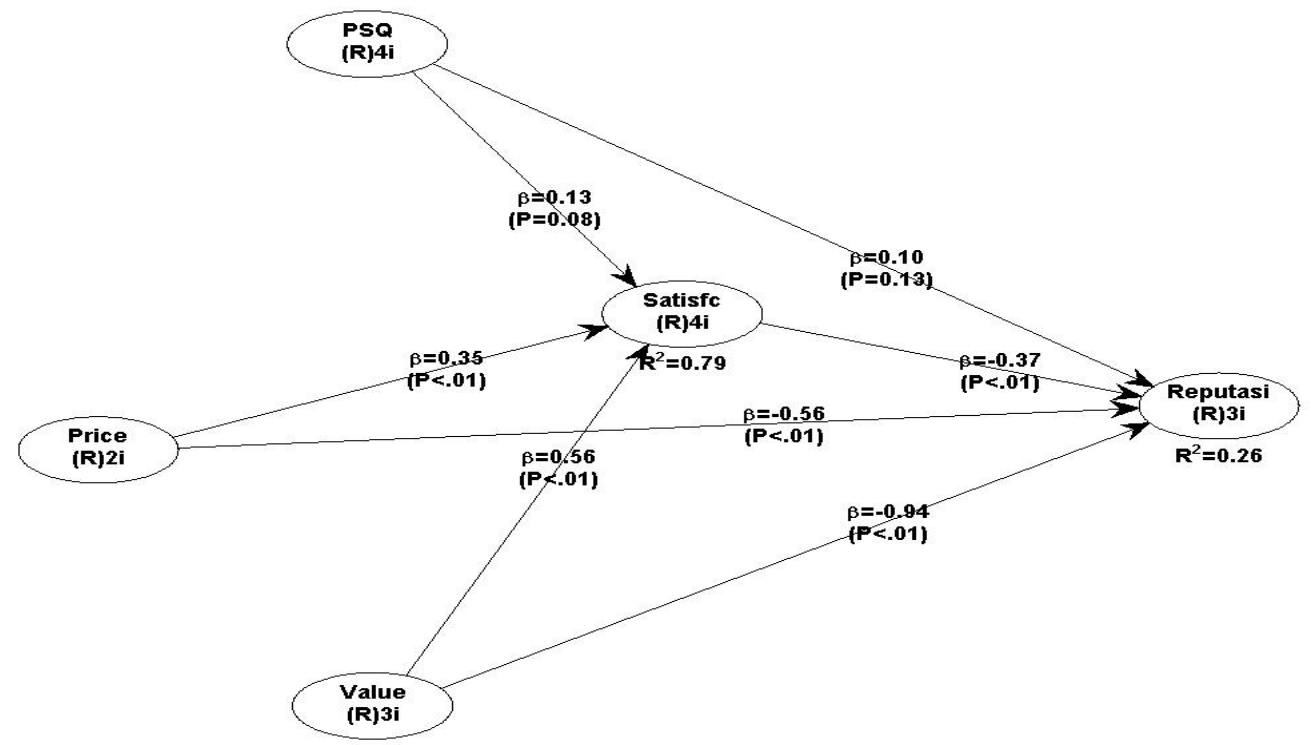

Fig. 1. Path Coefficient dan P Value

Tabel 5. Path Coefficient dan $P$ Values

\begin{tabular}{lccc}
\hline \multicolumn{1}{c}{ Correlation } & Path Coefficient & P-values & Information \\
\hline PSQ $\rightarrow$ Satisfaction & 0.129 & 0.079 & Rejected \\
Price $\rightarrow$ Satisfaction & 0.348 & $<0.01$ & Accepted \\
Value $\rightarrow$ Satisfaction & 0.561 & $<0.01$ & Accepted \\
PSQ $\rightarrow$ Reputation & 0.104 & 0.13 & Rejected \\
Price $\rightarrow$ Reputation & -0.564 & $<0.01$ & Rejected \\
Value $\rightarrow$ Reputation & -0.937 & $<0.01$ & Rejected \\
Satisfaction $\rightarrow$ Reputation & -0.366 & $<0.001$ & Rejected \\
\hline
\end{tabular}

The following is a description of the results of hypothesis testing which can be explained as follows: 
1. Testing H1: Perceived Service Quality (PSQ) affects Satisfaction. The calculation results in table 5 show that the resulting P-values are $0.079>0.05$ and the path coefficient is 0.129 which is positive. $p$ value of 0.079 is greater than 0.05 which means it is not significant, meaning that $\mathrm{H} 1$ is rejected.

2. Testing H2: Price affects Satisfaction. The calculation results in table 5 show that the resulting P-values are $0.001<0.05$ and the path coefficient is 0.348 which is negative. $p$ value of 0.001 is smaller than 0.05 which means significant, meaning that $\mathrm{H} 2$ is accepted.

3. Testing H3: Value affects Satisfaction. The results of the calculations in table 5 show that the resulting P-values are $0.001<0.05$ and the path coefficient is 0.561 which is positive. $p$ value of 0.001 is smaller than 0.05 which means significant, meaning that $\mathrm{H} 3$ is accepted.

4. Testing H4: Perceives Service Quality (PSQ) affects reputation. The calculation results in table 5 show that the resulting P-values are $0.13>0.05$ and the path coefficient is 0.104 which is positive. $p$ value of 0.13 is greater than 0.05 , which means it is not significant, meaning that $\mathrm{H} 4$ is rejected.

5. Testing H5: Price affects reputation. The results of the calculations in table 5 show that the resulting P-values are $0.01<0.05$ and the path coefficient is 0.564 which is negative. $p$ value of 0.01 is smaller than 0.05 which means significant, meaning that $\mathrm{H} 5$ is rejected.

6. Testing H6: Value affects reputation. The calculation results in table 5 show that the resulting P-values are $0.01<0.05$ and the path coefficient is 0.937 which is negative. $p$ value of 0.01 is smaller than 0.05 which means significant, meaning that $\mathrm{H} 6$ is rejected.

7. Testing H7: Satisfaction affects reputation. The results of the calculations in table 5 show that the resulting P-values are $0.001<0.05$ and the path coefficient is 0.3661 which is negative. $p$ value of 0.001 is smaller than 0.05 which means significant, meaning that $\mathrm{H} 7$ is rejected.

The test results The coefficient of determination is presented as follows:

Table 6. R-squared

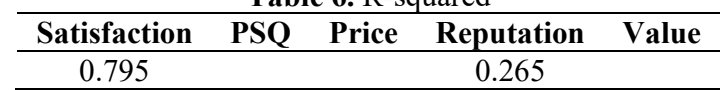

Based on the results of the output in table 6 , the R squared value is 0.795 which means that the effect of the variable perceived service quality (X1), perceived price (X2), and perceived value (X3) on user satisfaction (Y1) is $79.5 \%$ and the rest $20.5 \%$ is influenced by other variables outside of this research model. The results showed that the effect of perceived service quality (X1), perceived price (X2), perceived value (X3), and user satisfaction (Y1) on institutional reputation (Y2) was 0.265 or $26.5 \%$. The results of this study are in accordance with the theory that satisfaction is influenced by perceived of service quality(Sultan et al., 2013; Wang et al., 2020), perceived of price (Gray \& Bray, 2019; Stojic et al., 2020), and perceived of value(Hadiansah, 2017; Suanmali et al., 2014).

\section{Conclusion}

The results of this study concluded that:

a. The level of satisfaction of users of construction project products from government cooperation with business employees is in the good category with an average index value of 3.27 on a scale of 4 . 
b. Perceived service quality (PSQ) has no significant positive effect on user satisfaction of the government-business entity partnership project, so $\mathrm{H} 1$ is rejected.

c. Perceived of Price has a positive and significant effect on user satisfaction of the government-business entity partnership project, so $\mathrm{H} 2$ is accepted.

d. Perceived of value has a positive and significant effect on user satisfaction of the government-business entity partnership project, so $\mathrm{H} 3$ is accepted.

e. Perceived of Service Quality has no significant positive effect on reputation of the government-business entity partnership project cooperation, so $\mathrm{H} 4$ is rejected.

f. Perceived of price has a negative and significant effect on reputation of the governmentbusiness entity partnership project cooperation, so $\mathrm{H} 5$ is rejected.

g. Perceived of value has a negative and significant effect on reputation of the governmentbusiness entity partnership project cooperation, so H6 is rejected.

h. Satisfaction User has a negative and significant effect on reputation of the governmentbusiness entity partnership project cooperation, so $\mathrm{H} 7$ is rejected.

\section{References}

[1] Casnoto, H. (2017). Pembiayaan Pembangunan Infrastruktur pada Daerah Otonom melalui Skema Kerjasama Pemerintah dan Badan Usaha Public Private Partnership Scheme in Local Government Infrastructure Development (Case Study in the Government of Bandung Municipality).

[2] Duque, L. C. (2013). A framework for analysing higher education performance: students' satisfaction, perceived learning outcomes, and dropout intentions. Total Quality Management and Business Excellence, 25(1-2), 1-21. https://doi.org/10.1080/14783363.2013.807677

[3] Gray, M., \& Bray, J. R. (2019). Evaluation in the Australian Public Service: current state of play, some issues and future directions Appendix B. March. https://www.anzsog.edu.au/preview-documents/research-output/5367-appendix-bevaluation-in-the-aps

[4] Hadiansah, I. (2017). The Influence of Customer Perceived Value Toward Customer Satisfaction in Jababeka Golf \& Country Club. Journal of Management Studies, 2(2), 74-84.

[5] Hair, J. F., Sarstedt, M., Hopkins, L., \& Kuppelwieser, V. G. (2014). Partial least squares structural equation modeling (PLS-SEM): An emerging tool in business research. European Business Review, 26(2), 106-121. https://doi.org/10.1108/EBR-102013-0128

[6] Henseler, J. (2017). Bridging Design and Behavioral Research With Variance-Based Structural Equation Modeling. Journal of Advertising, 46(1), 178-192. https://doi.org/10.1080/00913367.2017.1281780

[7] Nguyen, H. T., Nguyen, H., Nguyen, N. D., \& Phan, A. C. (2018). Determinants of customer satisfaction and loyalty in Vietnamese life-insurance setting. Sustainability (Switzerland), 10(4), 1-16. https://doi.org/10.3390/su10041151

[8] Stojic, D., Ciric, Z., Sedlak, O., \& Horvat, A. M. (2020). Students' views on public transport: Satisfaction and emission. Sustainability (Switzerland), 12(20), 1-16. https://doi.org/10.3390/su12208470

[9] Suanmali, S., Chankao, K., \& Ammarapala, V. (2014). Road Infrastructure and Road User's Satisfactions: A Case Study of Motorway Route 7, Thailand. SHS Web of 
Conferences, 12, 01028. https://doi.org/10.1051/shsconf/20141201028

[10] Sultan, M. A., Marsaoly, N., Yudasaputra, M. T., \& Pasri, A. A. (2013). Kajian Tingkat Kepuasan Pengguna Infrastruktur Transportasi Di Kabupaten Halmahera Utara. SIPILsains, 3(5), 59-74.

[11] Wahyuni, P. I., Hardjomuljadi, S., \& Sulistio, H. (2018). Identifikasi Variabel Sistem Insentif Dalam Proyek Kerjasama Pemerintah Swasta ( Kps ) Jalan Tol. Paduraksa, 7(2), 239-256.

[12] Wang, Y., Zhang, Z., Zhu, M., \& Wang, H. (2020). The Impact of Service Quality and Customer Satisfaction on Reuse Intention in Urban Rail Transit in Tianjin, China. SAGE Open, 10(1). https://doi.org/10.1177/2158244019898803

[13] Yuniarti, Y., \& Junita, F. (2017). Prinsip Proporsionalitas Dan Governance Terhadap Alokasi Dan Transfer Risiko Dalam Skema Kerjasama Public-Private Partnership (Ppp). Yuridika, 32(3), 541. https://doi.org/10.20473/ydk.v32i3.4633 